\title{
Prevalence of iron deficiency and thalassemia in patients presenting Tertiary Care Hospital.
}

1. MBBS, FCPS (O \& G)

Senior Registrar Gynae \& Obs

Nishtar Hospital, Multan.

2. MBBS

Resident Gynae \& Obs Nishtar Hospital, Multan.

3. MBBS

Resident Gynae \& Obs

Nishtar Hospital, Multan

4. MBBS

Resident Gynae \& Obs Nishtar Hospital, Multan

5. MBBS, FCPS (O \& G)

Medical Officer

Nishtar Hospital, Multan.

6. MBBS

Resident Gynae \& Obs

Nishtar Hospital, Multan.

Correspondence Address:

Dr. Nadia Taj

Department of Gynae \& Obs

Nishtar Hospital, Multan.

dr.nadia.taj@gmail.com

Article received on:

$11 / 03 / 2020$

Accepted for publication:

20/05/2020

\section{INTRODUCTION}

In the developing countries, anemia is regarded a general health issue, also it is roughly estimated that about two billion people are suffering from anemia throughout the world. There are varying causes of anemia like deficiency of nutrition, infection and hemoglobin disorder. ${ }^{1}$

Anemia can be defined as decrease in the level of $\mathrm{Hb}$ in blood which cause to reduce the oxygen carrying capacity of blood. Symptoms of anemia are difficulty in breathing, severe headache, fatigue or angina, in case of severe anemia., ${ }^{2,3}$ Anemia of iron deficiency [IDA] may be occurred due to deficiency of iron in diet, malabsorption of iron in the intestine, and acute loss of blood. ${ }^{4}$

Thalassemia is defined as the genetic disorder of hemoglobin synthesis due to non-formation of one or more chain of globin. ${ }^{5}$ thalassemia is the worldwide disorder as it is estimated that in the coming 20 years 9 lac individuals are expected to born with thalassemia ${ }^{6}$ it is visualized that almost $1.5 \%$ individuals from world population are carriers of this disease. ${ }^{7}$

It is necessary to distinguish between anemia of iron deficiency and thalassemia to prevent from unusual treatment of iron as in thalassemia patient is restricted to intake of iron. ${ }^{8} \mathrm{~A}$ proper differential identification between the beta-TT and IDA depends upon results of hemoglobin percentage, serum iron and ferritin concentration. For the determination of red cells as the index of beta-TT, electronic cell counter are used. Use of index to notice subject having higher likelihood to decrease cost of examination. ${ }^{9}$ In the study frequency of iron deficiency anemia was noticed in $20 \%$ of patient. Since IDA and thalassemia is usual in prenatal patient, no general study is assessible to examine its frequency in Panjab.

Hemoglobinopathies is commonly genetic disease, almost seven percent of world population 
is carrier of this disease, and 3 lack to 5 lack infants are born with acute hemoglobin disease. They are classified depending upon the globin chain and this disease leads to decreased production of normal globin chain or tertiary globin chain. Hemoglobin should have the true structure and managed in appropriate way that alpha chains accurately matches the beta chains. ${ }^{10}$

Thalassemia refers to hemoglobinopathies identified by completely or partially decreased production of one from two types of peptide chains [alpha or beta chain] caused due to nonsense mutation or missense mutation or frameshift mutation of genes that are controlling the formation of hemoglobin chains. Many types of thalassemia have been reported depending upon genes to be effected to be mutated, most common type of medical importance is betathalassemia. ${ }^{11}$ In this we investigate the frequency of iron deficiency anemia and thalassemia in patients presented at tertiary care hospital of Multan, Pakistan.

\section{MATERIAL \& METHODS}

This cross sectional study was conducted in department of obstetrics and gynoecology, Nishtar hospital, Multan from $1^{\text {st }}$ January 2018 to $31^{\text {st }}$ December 2019. Data of 261 patient was collected in order to present the results of the study. Patients from age 24 to 34 having HB level less then $10.5 \mathrm{~g} / \mathrm{dl}$ with age of gestation 24-34 week were included in study. After taking permission from ethical committee of the hospital, written consent was taken from patient before including data of patient in research. Non probability consecutive sampling technique was used.

Blood of the patient was collected by aseptic measures for counting of hemoglobin and hemoglobin electrophoresis HBA2 [>7]. Gestational age was predicted upon the last menstrual periods. Patients with age less than 24 and greater than 34 were excluded from study.

Data was analyzed by using the SPSS version 23. Mean and S.D was calculated and presented for quantitative variables like gestational age, parity and age of patient. Frequency and percentages were calculated and presented for categorical data like the iron deficiency anemia and thalassemia. $P$ value less than or equal to 0.05 was supposed to be statistically significant.

\section{RESULTS}

Range of age in this study was from 24 to 34 years, average gestational age $33.2 \pm 2.11$ week, average parity $1.46 \pm 1.3$, average gravida was $2.34 \pm 1.34$ is shown in Table-I. According to economic status of patients three categories were made poor, middle class and rich. $11.5 \%$ of patients belong to a poor economic status, $75.5 \%$ with middle class and $12.3 \%$ with rich Table-II. Thalassemia was diagnosed in 15(5.7\%) of patients and and iron deficiency anemia was found in $30(11.5 \%)$ of patients.

\begin{tabular}{|c|c|c|}
\hline \multicolumn{2}{|c|}{ Demographic } & Mean $\pm S D$ \\
\hline \multicolumn{2}{|l|}{ Age of patient } & $29.9 \pm 2.3$ year \\
\hline Gestational age & & $33.2 \pm 2.11$ week \\
\hline \multicolumn{2}{|l|}{ Parity } & $1.46 \pm 1.3$ \\
\hline \multicolumn{2}{|l|}{ Gravida } & $2.34 \pm 1.34$ \\
\hline \multicolumn{3}{|c|}{ Table-I. Demographic variables } \\
\hline $\begin{array}{l}\text { Socioeconomic } \\
\text { Status }\end{array}$ & No. of Patients & Percentage (\%) \\
\hline Poor & 30 & $11.5 \%$ \\
\hline Middle class & 197 & $75.5 \%$ \\
\hline Rich & 32 & $12.3 \%$ \\
\hline Total & 260 & $100 \%$ \\
\hline \multicolumn{3}{|c|}{$\begin{array}{l}\text { Table-II. Percentage of patients regarding their } \\
\text { socioeconomic status }\end{array}$} \\
\hline Thalassemia & No. of Patient & Percentage \% \\
\hline Yes & 15 & $5.7 \%$ \\
\hline No & 245 & $94.2 \%$ \\
\hline Total & 260 & $100 \%$ \\
\hline \multicolumn{3}{|c|}{ Iron deficient anemia } \\
\hline Yes & 30 & $11.5 \%$ \\
\hline No & 230 & $88.4 \%$ \\
\hline Total & 260 & $100 \%$ \\
\hline \multicolumn{3}{|c|}{$\begin{array}{c}\text { Table-III. Percentage and frequency of patients } \\
\text { regarding thalassemia }\end{array}$} \\
\hline
\end{tabular}

\section{DISCUSSION}

Among all the populations studied for iron deficient 
anemia and thalassemia syndrome, remarkably beta-thalassemia is highly widespread microcytic hypochromic anemias in all over the world. ${ }^{12,13}$ Harthoorn Lasthuize et $\mathrm{al}^{14}$ conducted a study on this topic and reported that deficiency of iron is the important provenance of identification interference in laboratory tests for diagnosis of $\mathrm{HbA} 2$ that can give positive or negative outcomes.

Steinberg et $\mathrm{al}^{15}$ documented that intracellular deficiency of iron decreases alpha-globin chain manufacturing relatively to that of non alphaglobin chain, when the production of beta chain is decreased, beta globin chain competes in much effective manner for alpha-globin chain than $\delta$-globin chain, that results in decreased level of $\mathrm{HbA} 2$.

In a study conducted by Madan et $\mathrm{al}^{16}$ reported that beta-thalassemia doesn't confer benefit in regulating iron balance, and that $\mathrm{HbA} 2$ is not prominently decreased in presence of IDA that was similar with current study.

Steinberg et $\mathrm{al}^{17}$ concluded in his study that increased $\mathrm{HbA} 2$ level is established screening test for BTT. But, a few contradictory report questions the authenticity of the tests to screen BTT in existence of iron inadequacy. Negligence to eliminate iron deficiency in the victim with alphathalassemia syndrome causes the continuance of supplemental therapy of iron for enlarged duration of time, and in result, overloading of iron can cause secondary hemochromatosis. If overloading of iron continued for about 12-13 years, it can cause harm to many organs of body, includes cardiac, hepatic dysfunction.

Chotnopparatpattara et $a{ }^{18}$ managed a study on the prevalence and possibility factor of anemia in pregnant women. In our study prevalence of iron deficient anemia was observed in $20 \%$ of patient. In a study by Arora $S$ et al $^{19}$ has observed the frequency of iron deficient anemia was $90.1 \%$ and beta-thalassemia was $4.5 \%$ in patient. In our study iron deficient anemia was observed in $88 \%$ patient and thalassemia was observed in 5.5\% patient.
Merrill Rebecca et $\mathrm{al}^{20}$ conducted a study on this topic and concluded that prevalence of thalassemia in rural areas is very high but iron deficiency was found minimum due to intake of iron rich diet. Prevalence of thalassemia was found $28 \%$ in this study. In our study thalassemia was found only $5.7 \%$ of patients.

\section{CONCLUSION}

Screening for carriers of thalassemia carrier should be provided to all pregnant women. Ideally it should early in pregnancy or as soon as possible. Application of simple screening of carrier is possible in Pakistan.

Copyright@ 20 May, 2020.

\section{REFERENCES}

1. Kayode 0 , Adeola 0 , Oladunjooge A. Anemia in developing countries: Burden and prospects of prevention and control. In: Silverberg D, editor. Anemia. 1 st ed. Croatia: InTech-Open; 2012. p. 115-6.

2. Abdulbasit N. Comparhavior of red blood cells indices in iron deficiency anemia and P-thalassemia tr Iraqi J Hematol. 2016; 5:183-6.

3. Bekele A, Tilahup M, Mekuria A. Prevalence of anemia and its associated factors among pregnant women attending antenatal care in health institutions of Arba Minch Town, Gamo Gofa Zone, Ethiopia: A cross-sectional study. Anemia. 2016; 2016:1073192.

4. Clara C. Iron-deficiency anemia. N Engl J Med. 2015; 372:1832-43.

5. Weatherall DJ. Haemoglobin and the inherited disorders of globin synthesis. In: Hoffbrand AV, Catovsky D, Tuddenham EG, editors. Postgraduate Haematology. $5^{\text {th }}$ ed. UK: Blackwell Publishing; 2005. p. 88-9.

6. Karimzaei T. Knowledge, attitude and practice of carrier thalassemia marriage volunteer in prevention of major thalassemia. Glob J Health Sci. 2015; $7(5): 364-70$.

7. Soliman AR, Kamal G, Elsalakawy A, Mohamed TH. Blood indices to differentiate between P-thalassemia trait and iron deficiency anemia in adult healthy Egyptian blood donors. Egypt J Haematol. 2014; 39:91-2.

8. Massey AC. Microcytic anemia. Differential diagnosis and management of iron deficiency anemia. Med Clin North Am. 1992; 76:549-66. 
9. Vehapoglu A, Ozgurhan G, Demr AD, Uzuner S, Nursoy $M A$, Turkmen $S$, et al. Hematological indices for differential diagnosis of Beta) Ilalassemia trait and iron deficiency anemia. Anemia 2014; 1(6)576-738.

10. Li X, Allen RP, Earley CJ, Liu H, Cruz TE, Edden RA et al. Brain iron deficiency in idiopathic restless legs syndrome measured by quantitative magnetic susceptibility at 7 tesla. Sleep Med 2016; 22:75-82.

11. Danjou F, Anni F, Galanello R. Beta-thalassemia: From genotype to phenotype. Haematologica 2011; 96(11):1573-75.

12. Sirdah M, Tarazi I, Al Najjar E, Al Haddad R. Evaluation of the diagnostic reliability of different $R B C$ indices and formulas in the differentiation of the $\beta \square$ thalassaemia minor from iron deficiency in Palestinian population. Int J Lab Hematol. 2008 Aug; 30(4):324-30.

13. Demir A, Yarali N, Fisgin T, Duru F, Kara A. Most reliable indices in differentiation between thalassemia trait and iron deficiency anemia. Pediatr Int. 2002 Dec 1; 44(6):612-6.

14. Harthoorn Lasthuizen EJ, Lindemans J, Langenhuijsen MM. Influence of iron deficiency anaemia on haemoglobin A2 levels: Possible consequences for betathalassaemia screening. Scand J Clin Lab Invest. 1999; 59(1):65-70.
15. Steinberg MH, Adams JG. Hemoglobin A2: Origin, evolution and aftermath. Blood. 1991; 78(9):2165-77.

16. Madan N, Sikka M, Sharma S, Rusia U. Phenotypic expression of hemoglobin $\mathbf{A} 2$ in betathalassemia trait with iron deficiency. Ann Hematol. 1998; 77(3):936.

17. Steinberg MH, Adams JG. Hemoglobin A 2: Origin, evolution after math. Blood. 1991; 78:2165-77.

18. Chotnopparatpattara P. Prevalence and risk factors/ anemia in pregnant women. J Med Assoc Thai. 2003; 86(11):1001-7.

19. Arora S, Rana D, Raychaudhuri S, Dhupia JS. Coexistence of iron deficiency and thalassemia trait: A study in antenatal females. Int J Res Med Sci. 2017; 5:5362-6.

20. Merrill Rebecca D, Shamim Abu A. High prevalence of anemia with lack of iron deficiency among women in rural Bangladesh: A role for thalassemia and iron in groundwater. Asia Pacific J Clin Nutr 2012; $21(3)$ :41624.

\begin{tabular}{|c|l|l|l|}
\hline \multicolumn{3}{|c|}{ AUTHORSHIP AND CONTRIBUTION DECLARATION } \\
\hline Sr. \# & Author(s) Full Name & \multicolumn{1}{|c|}{ Contribution to the paper } & Author(s) Signature \\
\hline 1 & Nadia Taj & Conceive idea, Design study. \\
\hline 2 & Saba Javed & Data collection, Manuscript Writing. \\
\hline 3 & Munazza Munir & Data collection, Literature review. \\
\hline 5 & Anam Naz & Data analysis. \\
\hline 6 & Ayesha Karim & Statistical analysis, Final approval. \\
\hline
\end{tabular}

